\title{
ENTREPRENEURSHIP GROWTH IN OMAN: POSITION, PROSPECTS AND GROWTH OF ENTREPRENEURAL EDUCATION
}

\author{
Maria Teresa Matriano', David Suguku² \\ ${ }^{1}$ Asst. Prof. Dr., Middle East College, Oman, maria@mec.edu.om \\ ${ }^{2}$ Lecturer, Middle East College, Oman, david@mec.edu.om
}

\begin{abstract}
The term 'Entrepreneurship' has certain connotations to diverse groups of people. An entrepreneur is identified as one who undertakes to organize, manage, and assume the risks of business. Shane and Venkataraman (2000) define entrepreneurship as involving the study of sources of opportunities; the processes of discovery, evaluation, and exploitation of opportunities; and the set of individuals who discover, evaluate, and exploit them. This paper considers the current position and potential of innovative and entrepreneurial thinking for effective problem solving and change management in Oman. The paper explores the initiatives that the government of Oman has sought in building the level of awareness and engagement with the innovation and entrepreneurship agenda within education system, especially tertiary level programs. It reviews the educational aims as well as the uptake of entrepreneurial education and training in Oman. This paper seeks to identify how incorporating entrepreneurship into educational curriculum will contribute to the future growth of entrepreneurship in the country while enhancing the entrepreneurship agenda to include non- educational constituencies, actors and community at large. In recognizing the central role of creativity and innovation in entrepreneurship and in the generation of new ideas, where appropriate the core challenges of protecting those new ideas which have commercial and social value. The paper debunks one of the myths that entrepreneur are academic and social misfits while considering adopting social, economic and academic leadership trendsetter and change agent that the society and country needs at large. The contemporary Omani entrepreneur is to be viewed as a professional, with entrepreneurship education highlighting the issues related to the formation, development, and operations of small-scale and micro enterprises.
\end{abstract}

Keywords: entrepreneurship, entrepreneur, entrepreneurial thinking, entrepreneurship agenda, entrepreneurial education, economic growth

\section{INTRODUCTION}

Entrepreneurship is a result of conductive economic conditions such as easy availability of raw materials, technology and infrastructure; favorable tax and industrial policies, marketing opportunities and accessible finance. The concept of entrepreneurship can best be understood by a discussion of some of the modern theories of entrepreneurship. Business dictionary defines entrepreneurship as the capacity and willingness to develop, organize and manage a business venture along with any of its risks to make a profit.

\section{ENTREPRENEURSHIP GROWTH IN OMAN}

According to the Kauffman Foundation, entrepreneurship is the process of providing individuals with the concepts and skills to recognize opportunities that others have overlooked and to have the insight, self- 
esteem and knowledge to act where others have hesitated. It includes instruction in opportunity recognition, marshalling resources in the face of risk, and initiating a business venture. It also includes instruction in business management processes such as business planning, capital development, marketing, and cash flow analysis. Venkataraman (1997) contends that entrepreneurship is defined in terms of who the entrepreneur is and what he or she does which renders the definition incomplete because it does not take into account the available opportunities. Thus in 2000, Shane and Venkataraman came up with a definition that covers most of the processes involve in entrepreneurship. They define entrepreneurship as involving the study of sources of opportunities; the processes of discovery, evaluation, and exploitation of opportunities; and the set of individuals who discover, evaluate, and exploit them. Economists across time have attempted to explain the entrepreneurial drive. While they may vary in ideas, they are unanimous in acknowledging that entrepreneurship is a concept that is a central factor in economic development.

Joseph Schumpeter, on the other hand, holds the innovation theory of entrepreneurship. He put emphasis on the innovation, foresight and creativity of entrepreneurs but fails to consider the equally important characteristics of taking risks and good organizational skills. Harvey Leibenstein (1922-1994) looks at entrepreneurs as fillers of market deficiencies. According to him, entrepreneurs recognize market trends, develop goods and services that are in demand but not in supply and determine activities that are profitable. Entrepreneurship will increasingly play a more important role in the current economic global development. Developed countries have acknowledged the value of entrepreneurship and large businesses have given way to what is called entrepreneurial economy. While developing countries still lag behind in terms of entrepreneurial development, there are ongoing initiatives especially in the Arab Gulf region to nurture creation of new enterprises. To name a few, the Knowledge Economic City in Saudi Arabia, the Mohamed Bin Rashid Al-Maktoum Foundation, the Qatar Science and Technology Park and Knowledge Oasis in Muscat, Oman.

Entrepreneurship Education is primarily concerned with providing learners with the requisite knowledge, skills and attitude of creating and operating their own new business ventures successfully, while using the available resources to develop themselves and the country in general. There is increasing attention to entrepreneurship and entrepreneurship education in Oman as evidenced by its Technical Vocational Education and Training (TVET) practices with the Ministry of Manpower running Colleges of Technology to enable delivery of knowledge and skills required by Oman (Al-Ghassani, 2010). Entrepreneurship education in Oman includes research, teacher training, curriculum development, pilot projects, and collaboration with NGOs.

Vision Oman 2020 is a twenty-five year (1996 to 2020) plan for the economic development and future of Oman which puts emphasis in the development of small and medium enterprises. As part of the initiative to spur the growth of entrepreneurial training, programmes have been developed and adopted in Oman. The country has embarked on a support program as follows: the SANAD programme which is an initiative to promote entrepreneurship among young people by providing loans and expertise to new graduates; Know about Business (KAB) is another initiative by the Omani government under the auspices of the International Labour Organization (ILO) which focuses on the management training of entrepreneurs to develop their entrepreneurial attitude.

The 'Intilaaqah' programme is part of LiveWIRE, the worldwide initiative of the Shell group. It empowers young entrepreneurs through counselling and consultancy services to start their own businesses and boasts of having trained over 4000 entrepreneurs since inception up-to 2015. On the other hand, the Nizwa College of Technology developed the BSC (Business Simulation Classes), a project that integrates entrepreneurship with college academic programme. Middle East College, in their annual celebration of MEC Week has put emphasis on entrepreneurship as a core theme where a series of entrepreneurship workshops are designed to spur entrepreneurship across the entire program spectrum. The institution is committed to nurturing creativity, innovation and businesses where students shall be accorded an opportunity to manage an actual business enterprise providing them an experiential learning through ideas generation and business experience that is beyond taught classroom knowledge.

By encouraging and nurturing entrepreneurship initiatives, this will benefit the country in the long term given low enterprise establishment and growth rate. The contribution of entrepreneurship to economic growth and employment creation cannot be denied especially in the context of Oman. However, the role of the government is crucial. As regulators, the state provides the appropriate rules and guidelines by which entrepreneurs must adhere. In the absence of proper regulatory framework, adverse outcomes may result in sheer profiteering and speculation.

The Sultanate of Oman has a small private sector and upcoming national entrepreneurial activity. To secure Oman's economy, it must reduce its reliance on its oil revenues (Magh \& McCoy, 2014). There is a need to foster the entrepreneurial spirit in the country because its oil reserves are estimated to last less than 20 years. Economic diversification through entrepreneurship must start now. However, there are challenges to this plan, first is the bureaucracy. Out of 183 countries in the world, Oman is ranked 65 in ease of doing 
business in 2010 (Word Bank, 2010). This is a deterrent for those new business ventures which if addressed will contribute to the ease of doing business and facilitating start -ups.

A second challenge is the labor market. According to a 2009 report on Arab Human Capital Challenge, 62 percent of Arab employers believe that there is a lack of supply for qualified national workers and the 2009 Global Competitive Report shows that poor work ethics in the labor force is the third most problematic factor for doing business in Oman.

A third challenge is the culture and social norms of Oman which is similar to many Arab countries. In the 1980 study by Hofstede, the characteristics of these countries are high in uncertainty avoidance, high on masculinity and love in individualism who do not favor entrepreneural growth. The greater socio-cultural fabric in Oman is risk averse; whereas risk has been and will always be part of entrepreneurship. Although these cultural factors will require time to change, they should be overcome through attitude change and education to pursue entrepreneurial development.

A fourth challenge which is of great significance to the authors is education and training. Fifty percent of Arab CEO's believe that products of the education system are not prepared for entrepreneurship challenge (Arab Human Capital Challenge, 2009). In Oman, a majority of the learners focused more on memorization and theory. The educators find it very challenging to define the clear methods of encouraging critical thinking initiative and the ability to bridge the gap between theory and application. A key player in public university in the country is Sultan Qaboos University that offers two undergraduate courses and one MBA programme related to entrepreneurship. Given the positive impact of entrepreneurship to the economic growth of a country, policy makers should create the entrepreneurial culture by integrating it fully in education system and in the curriculum of all universities and colleges.

The attitude and mindset towards entrepreneurship is another challenge that must be addressed. Lim (2011) made this clear by saying, "Positive attitude is a very important mindset that entrepreneurs must have. Besides having specialized or technical skills, if they do not have the positive attitude, they will not be able to achieve the goals that they want to achieve." This paradigm shift on entrepreneurship must start with the education sector since it is where future entrepreneurs will come. Teixeira (2010) states that because of the growing emphasis on entrepreneurship as the incubator and catalyst for economic progress, policy makers and educators have developed strategies to support entrepreneurship.

Entrepreneurs face a host of challenges especially at the beginning of their businesses and more so at start-up stages. They are confronted by a range of challenges and seldom have sufficient learning support mechanisms to enhance skills in confronting the challenges. The education system must take measures to provide opportunities for learning and to engage in actual entrepreneurial enhancement projects and activities. Activities must be made available wherein students put the theories they learned into practical use. These can be done by business simulation with the aim to understand the entire business cycle, how to assess risks and how to identify opportunities and developing actual business plans. Underlying a sound entrepreneurial education is the ability to assess, evaluate and provide appropriate training areas that address challenges faced by entrepreneurs and administer learning interventions to address the challenges.

For the purpose of this paper, it shall address challenges in business in reference to the major activities undertaken in a business, whereas tasks are seen as specific pieces of work that can be done to meet the challenges. Examples of challenges and tasks are given in Table below.

Table: Tasks and challenges in business

\begin{tabular}{|l|l|}
\hline Challenges & Tasks undertaken to meet challenges \\
\hline Raising Funds / Capital & $\begin{array}{l}\text { - Applying for a loan } \\
\text { - Sourcing credit facilities from suppliers } \\
\text { - Expenditure control }\end{array}$ \\
\hline Marketing goods/services & $\begin{array}{l}\text { - Advertising } \\
\text { - Costing and choices on product /services } \\
\text { - Market survey and assessment }\end{array}$ \\
\hline Managing funds & $\begin{array}{l}\text { - Budgeting and budget control } \\
\text { - Simple record keeping }\end{array}$ \\
\hline Maximizing profits & $\begin{array}{l}\text { - Controlling costs } \\
\text { - Sales promotion }\end{array}$ \\
\hline Procuring and operations & $\begin{array}{l}\text { - Suppliers' development } \\
\text { - Choice of the best suppliers } \\
\text { - Choice of alternative transport options } \\
\text { - Storage and warehousing } \\
\text { - Establishment of quality management processes to ensure } \\
\text { producing high quality products }\end{array}$ \\
\hline
\end{tabular}


Design of learning interventions to address the above listed areas is key in equipping potential entrepreneurs with tools and skills to handle their day to day roles. An entrepreneur is a person who operates a new enterprise or venture and assumes the accountability for inherent risks. One of the key risks facing entrepreneurs is lack of capabilities to confront challenges due to limited knowledge, skills and aptitude.

The purpose of the education system as a whole and entrepreneurial education in particular must be to create an ideology of self-reliance. The curriculum must cover elements of creative thinking skills, risk management, ability to identify opportunities, inculcating the right work ethics which are currently lacking among some Omani college graduates. It is not just about creating new business but being able to produce future leaders equipped with the required skills, training and attitude that will foster challenges and change the status quo. Although there are successful entrepreneurs with no entrepreneurial education, a research carried out in Germany shows that businesses started by individuals with university degrees tend to grow faster than those founded by non-academics (Araba, 2012). The strength of entrepreneurial education lies in its ability to influence the attitude of people towards entrepreneurship and acts as a catalyst for those who might lack confidence in going to business on their own.

The entrepreneurial environment of Oman is still a work in progress but interventions can be done to promote national entrepreneurship development. There are positive environmental factors that can facilitate and spur entrepreneurial growth in Oman. Political stability is the most attractive feature in the Sultanate based on international rating. It also has a free economy policy which is crucial for new business ventures. Based on the 2015 Index of Economic Freedom, Oman is the $56^{\text {th }}$ freest economy with an economic freedom score of 66.7. It is the $6^{\text {th }}$ from among 15 countries in the Middle East and North African regions. On the average, starting a business takes one week for the five procedures needed. The Omani government also has an extensive subsidy system for businesses especially for petroleum products. Other encouraging factors are the quality of living standards and a young population that will ensure sustainability of the entrepreneurial initiative.

To encourage investment, there are a number of support programs available including subsidized zones, funding and industrial parks wherein the government is placing heavy investment with a view to ensure future growth. Policymakers should understand that this initiative to make Oman an entrepreneurial economy is a long-term commitment. They have to be prepared to be patient and to persevere before they would be able to see tangible results.

Creating entrepreneurship policy also has to consider the Omani culture and values. The entrepreneurship environment must seamlessly weave into the fabric of Oman's uniqueness as a country. Embracing entrepreneurial education right from lower levels, proliferation within tertiary and higher learning institutions is critical towards having a population prepared to appreciate entrepreneurship as an alternative to employment. The mindset shift towards graduates as generators of production and employment creation is a result of a sound education system that underscores the knowledge, skills and attitude shift towards selfreliance, creative thinking and readiness for taking on new challenges.

There should be a synchronization, harmonization and advocacy for entrepreneurship development, with policy making and implementation capability to bridge the gap between bureaucracy and the entrepreneurs. Coordination among relevant various ministries and agencies must be provided as an incentive for supporting the Oman education system to spur entrepreneurship. Creating one stop-shop centers for business registration and removal of red-tape is critical in encouraging start-ups business.

Admittedly, entrepreneurship is a complex and multi-faceted process but it is the hope of the authors that this paper will bring Oman one step closer to become an entrepreneurial society.

\section{REFERENCE LIST}

Al-Ghassani, A.M. (2010). The Case Study of Oman. In M. Masri, M. Jemni, A.M. Al-Ghassani, \& A.A. Badawi, Entrepreneurship Education in the Arab States: A Joint Project between UNESCO and StratREAL Foundation, U.K. Case Studies on the Arab States (Jordan, Tunisia, Oman, and Egypt); UNESCO LB/2010/ED/PI/34.

Arab human capital challenge. (2009). Dubai, UAE: Mohammed Bin Rashid Al Maktoum Foundation in cooperation with Price Waterhouse Coopers.

Araba, S. (2012). Entrepreneurial education as a tool for reducing unemployment in Nigeria. Retrieved April 5, 2014 from the World Wide Web: http://www.academia.edu/2047944/Entrepreneurial_Education_as_a_tool_for_reducing_Unemployme nt_in_Nigeria

Blanke, J., Browne, C., Hanouz, M. D., Geiger, T., Mia, I., \& Sala-o-Martin, X. (2009). The global competitiveness report 2009-2010: World Economic Forum. 
Klein, P. (2014), Mark Casson's The Entrepreneur at 30. Organizations and Markets. Retrieved April 2, 2015 from the World Wide Web: http://organizationsandmarkets.com/2014/06/06/mark-cassons-theentrepreneur-at-30/

Kigenyi, F.D. (2007), Entrepreneurship Education for UACE and Colleges. Kampala, Uganda. p.10

Kaufman Foundation. - Retrieved April 12, 2015 from the World Wide Web: http://www.kauffman.org

Lim, Z. (2011). Positive attitude for entrepreneur. Retrieved from http://ezinearticles.com/?Positive-AttitudeFor-Entrepreneur\&id=452603 on April 1, 2015.

Magd, H. A. E. \& McCoy, M. P. (2014). Entrepreneurship in Oman: Paving the Way for a Sustainable Future. Procedia Economicd and Finance. 15: pp 1632-1640/

Mazzarol, T. (2012). The field of entrepreneurship research. Where is the promise where is the future. Retrieved from Centre for Entrepreneurial Management and Innovation on April 7, 2015. http://www.cemi.com.au/node/428

Shane, S. \& Venkataraman, S. (2000). The promise of entrepreneurship as field of research, Journal of Management. 25: 217-226

Schumpeter, A.A. (2011). The Theory of Economic Development: An Inquiry into Profits, Capital, Credit, Interest, and the Business Cycle.

Teixeria,A. A. C. (2010), Attitudes of higher education students to new venture creation, Industry \& Higher Education 24:5, pp. 1-19

Pratiknyo, Y.S. (2010). The Entrepreneurship Theory. Retrieved from PPM Manajemen on April 7, 2015. https://manajemenppm.wordpress.com/2013/07/05/the-entrepreneurship-theory-an-overview/.

World Bank. (2010). Doing Business 2010. Washington, DC: The World Bank Group, IFC and Palgrave MacMillan. 